\title{
Trees as Dialogue: Negotiating Boundaries with the Anne Frank Sapling Project
}

\author{
Stella M. Čapek \\ Hendrix College, USA
}

DOI: http://dx.doi.org/10.18778/1733-8077.16.3.03

\section{Keywords:}

Truth-Spots; Trees;

Social Justice;

Museums; Anne Frank

\begin{abstract}
My qualitative research paper focuses on the Anne Frank sapling installation at the Clinton Presidential Museum and Library in Little Rock, Arkansas. Saplings grafted from the tree that grew outside Anne Frank's window in Amsterdam while she wrote her famous diary are provided by the Anne Frank Center for Mutual Respect to organizations that will link the tree to dialogues about past and present social justice issues. Building on Thomas Gieryn's recent work on "truth-spots," I explore the sapling installation as a possible "truth-spot," and reflect on what kind of truth is supported there. From a symbolic interactionist perspective, I consider the sapling as a boundary-crossing entity that, together with other elements of the installation, stimulates reflection and inclusive dialogue, and fosters hope without shunning complexity. I discuss the sapling's ecological needs and material agency, since it is not a passive recipient of human meanings and orchestrations. I also comment on the changing role of museum installations and exhibit space in the context of social justice.
\end{abstract}

Stella M. Čapek is an Elbert L. Fausett Emerita Distinguished Professor of Sociology in the Sociology/Anthropology Department at Hendrix College. Her research interests include environmental justice, social change movements, green design, social constructions of self and identity, and a sociology of silence. She has published articles on environmental justice, tenants' rights, grassroots movements, urban/ community issues, ecological identity, and environmental health. She has co-authored two books, Community Versus Commodity: Tenants and the American City and Come Lovely and Soothing Death: The Right To Die Movement in the United States, and authored Building Partnerships That Work: Grassroots, Science, and Social Change, The Endometriosis Association Story. She also enjoys publishing creative nonfiction essays.

email address: capek@hendrix.edu 
Deep currents of meaning swirl around our culture(s) and brush through the branches of any tree or tree-place which is being encountered, experienced, narrated, or imagined at any given time. [Jones and Cloke 2002:19]

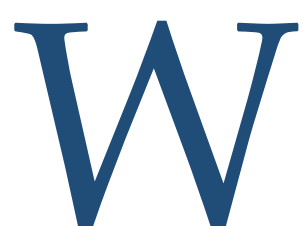
hy do human beings attach so much significance to trees? We do not fully know the answer, but there is a rich collection of cultural evidence about social relationships with trees (MacNaghten and Urry 2000; Rival 2001; Jones and Cloke 2002). My paper focuses on one tree in particular, a sapling installed at the Clinton Presidential Library and Museum in Little Rock, Arkansas (hereafter referred to as the Clinton Center). ${ }^{1}$ The tree sapling was derived from the horse chestnut tree that grew outside the "secret annex" where Anne Frank hid with her family in Amsterdam and wrote her famous diary. It is one of eleven saplings at selected sites in the U.S., including the iconic Liberty Park which commemorates the events of 9/11, and the West Front Lawn at the U.S. Capitol in Washington, D.C. The New York based non-profit Anne Frank Center USA (now renamed the Anne Frank Center for Mutual Respect [AFCMR]) has overseen the dispersal of the saplings, distributing them to "organizations with a demonstrated commitment to upholding Anne's vision for a peaceful, more tolerant world, as well as the capacity to properly care for the sapling and tree." ${ }^{2}$ The Clinton Center

\footnotetext{
${ }^{1}$ The Clinton Center includes the William J. Clinton Presidential Library and Museum, the University of Arkansas Clinton School of Public Service, and the Little Rock offices of the Clinton Foundation. See: https://www.clintonfoundation.org/clinton-presidential-center/about/overview.

${ }^{2}$ This quote is from an earlier Anne Frank Center website. In 2016, the organization was renamed the Anne Frank Center for Mutual Respect. According to the AFCMR mission statement, the organization "uses the diary and spirit of Anne Frank as unique tools to advance her legacy, to educate young people and communities in the U.S. and Canada about the dangers of intolerance, anti-Semitism, racism, and discrimination; and to
}

submitted a successful site proposal, and received a sapling in 2015.

A key aspiration shaping the sapling project seems to be that a "survivor" tree, representing new life and carrying a big story from the past into the present, can gently invite thoughtful discussion and education about difficult but important subjectsfor example, the Holocaust, and links to present and past injustices in the sapling's new location. Of course, the tree does not "work" alone-once it is planted, the AFCMR and the Clinton Center collaborate on educational programs that stem from its presence. Rooted in a new, socially significant setting, the sapling embodies a relationship between its point of origin (the Anne Frank tree in Amsterdam) and a new place (in this case, Little Rock, with its own history of injustices, and the Clinton Center with its connection to a former U.S. President). For this project, place is important. As Thomas Gieryn (2018:3) points out in his research on "truth-spots,"

...place matters mightily for what people believe to be true. We can better understand why some assertions or propositions or ideas become, for some people, credible and believable by locating them somewhere on the skin of the earth-and by asking what things are to be experienced at that spot and how this place is culturally understood.

My paper focuses on the sapling as an interactional "presence" that is both material and symbolic. In symbolic interactionist parlance, the sapling is a meaningful object to which human beings attribute symbolic significance (Blumer 1969). In that

inspire the next generation to build a world based on mutual respect." The website https://www.annefrank.com continues to undergo changes. 
capacity, it may serve as a "mnemonic device" to foster collective memory (Zerubavel 2003), and as a springboard for imagining a better future. The sapling may also serve as a "boundary object," an object about which different groups share common knowledge (the Anne Frank story), but also have unique, socially inflected perspectives on its meaning (Fox 2011; Bowker et al. 2016). This invites conversations from many angles and fosters the possibility of new discoveries about the world and about oneself.

But, the sapling is much more than an object upon which humans project symbolic meaning. Its materiality both constrains and enables human agendas. It is a living entity with its own needs, facing specific challenges (transplantation, and surviving in an ecologically unfamiliar climate zone). Alive and able to grow and change with the seasons, and capable of attracting birds and other creatures, it not only provides ecological lessons, but "calls out" to human beings aesthetically. In some cases, it may even take on the role of a non-human "significant other" in George Herbert Mead's sense (Čapek 2006). But, however engaging it may be, a tree sapling grows slowly in a world that increasingly craves speed and spectacle. Later in the paper, I discuss how the Sapling Project fits into changing ideas about "performance" expected from museum exhibits and installations in a fast-paced world linked to globalization, new understandings of leisure and entertainment, participatory approaches to discovering truth, and what some would call a postmodern desire for a personalized crafting of identity. Taking a cue from Gieryn's work, I also explore the sapling installation as a possible "truth-spot."

My paper is organized as follows. I begin with a brief discussion of the broader context of my proj- ect and research methods. Next, I review some key anthropological and sociological ideas about the "social life of trees" (MacNaghten and Urry 2000; Rival 2001). Following that, I briefly touch on the sapling's origins in Amsterdam, and then focus on its presence at the Clinton Center site, and how its role and agency are enmeshed in material and symbolic relations. Finally, I look at how this particular installation fits into a larger discussion about the changing role of museum/exhibit spaces in the $21^{\text {st }}$ century.

\section{Framework and Research Methods}

My qualitative research project began as an exploration of the social "afterlife" of two culturally significant trees which, after they died, were transformed into a symbol for bringing diverse communities together. One, a 175-year-old elm in Grand-Pré, Nova Scotia, was transformed into a sculpture, carved by three artists representing social groups that had claimed the same highly contested piece of land where the tree grew, and where the Acadian Deportation took place. ${ }^{3}$ The other, the approximately 170-year-old Anne Frank tree, lives on through carefully germinated and relocated saplings. My research project developed with both trees in mind, since both are used to simultaneously mark-and also to move beyond-past tragedies. This paper focuses on the second tree, but in my experience as a researcher and writer, the two trees (and settings) continue to dialogue with each other. My ongoing research project is part of a broader exploration of

\footnotetext{
${ }^{3}$ The three groups included the French Acadians who were expelled from Grand-Pré in 1755, the "New England planters" who replaced them and were given their land, and the First Nations indigenous and original residents, the Mi'kmaq. I wrote about the Nova Scotia tree in a creative nonfiction essay presented at the Association for the Study of Literature and Environment [ASLE] in 2012 (Čapek 2012).
} 
relationships between trees, human beings, social justice, and place. The most recent addition is climate change, which brings severe storms and new types of infestations that undermine the health and survival of many trees, including some of the oldest and most storied.

I began to research the Little Rock sapling in 2016, after reading about the installation in November 2015. I conducted targeted interviews with people knowledgeable about the project from a variety of angles, including those who first envisioned the project and its design, a site proposal author, Educational Programs staff at the Clinton Foundation and Clinton Presidential Library, and caretakers of the sapling. I also engaged in participant observation at the Clinton Center-attending talks, presentations, and performances (for example, the one-act play "A Conversation with Anne" based on Anne Frank's diaries that incorporates a dialogue with the audience), and a workshop for teachers brought by the AFCMR in June 2016. In 2017, I attended AFCMR former Executive Director Steven Goldstein's presentation on World Refugee Day at the Clinton Center, which linked the tree sapling with an expanding social justice agenda. I have also followed the development of the educational programs, and visit the sapling site regularly. In addition, I draw on a variety of documents and artifacts relating to the sapling project, such as newspaper articles, committee notes, the sapling proposal, photographs, workshop handouts, Clinton Center and AFCMR publications, and websites, among other sources.

\section{Tree Beings and Human Beings}

Although circumstances vary across time and space, human relationships to trees have been materially and culturally significant. Laura Rival, in her intro- duction to The Social Life of Trees (2001:1), notes that "trees provide some of the most visible and potent symbols of social process and collective identity." Trees are living beings, but as Brosse (1998) points out, they are alive in a different way from human beings, and this mysterious, ambiguous quality makes them intriguing. Materially, we depend on them to make our lives possible-they provide shade, fuel, food, raw materials for human projects, and-as we are increasingly aware-cleaner air and a brake on climate change. Human beings have endowed trees with cultural meaning, attributing to them qualities of wisdom, strength, longevity, innocence, power, rebirth, and enlisting them as witnesses and memory-keepers (Rival 2001; MacNaghten and Urry 2000; Jones and Cloke 2002; Schama 2004; Čapek 2006). Jones and Cloke (2002:214) note that "[t]rees are imagined according to a plethora of cultural constructs, circulating on different scales." In some traditions, birth placentas are planted under trees, to provide "roots" for a child in a specific place. Trees are planted ceremonially as international symbols of future goodwill. Trees may also be sacred guardians of numinous spaces reserved for ritual or initiatory occasions. MacNaghten and Urry (2000:168) conclude that despite "[p]owerfully different social myths...[m]any seem to feel particular affinities with trees since, like the upright human body, they appear majestically defenseless against progress, the modern and the scientific." Rooted, sheltering, yet vulnerable, trees are non-human agents that interact with human beings to "co-constitute" places. In doing so, they reveal a "bewildering range of creative capacities" (Jones and Cloke 2002:5).

This co-constitutive language emerges from scholarship that increasingly recognizes non-human as well as human agency, and their complex interactions and entanglements (Latour 1993; 2004; Ingold 
2011). In actor network theory (ANT), non-human "nature," including a tree, is agentic. Among other things, its material reality makes certain outcomes possible. Poet Genaro Kỳ Lý Smith (2014:78) captures just such an image in his poem "A Museum of Trees" about censorship during the Cultural Revolution in China. A tree hides an artist's forbidden paintings by day and reveals them at night: "He [the artist] and I know they are there, hidden during the day/ when the tight-fisted buds are afire in full yellow blooms/ and at night, they close their fingers to expose the paintings..." However, this imagined collaboration between a creative human being and a living tree is undermined by an oppressive social structure, since "no one looks up anymore." In another of Kỳ Lý Smith's poems (2014:16), trees at a reeducation (prison) camp "speak" through attached megaphones that serve as a voice of God/authority, telling internees when they might live or die. This serves as a reminder that trees are not only agents of life and beauty, but may be transformed by human agendas into messengers of hate and death. The United States has its own sad topography of lynching trees, as portrayed in the recently constructed National Memorial for Peace and Justice in Montgomery, Alabama.

I find Jones and Cloke's concept of "arbori-culture" (2002: 21) especially useful. The authors point out that "nature-society relations are continually unfolding in the contexts of specific places, in which meanings will arise from particular interactions between different assemblages of social, cultural, and natural elements" (Jones and Cloke 2002:1). Trees, they insist, must be seen as "both social constructions and as real dynamic material entities" (Jones and Cloke 2002:4). They interact in complex ways with place and human practices-like the trees in Norway that were recently found to have no tree rings for years, after being exposed to a chemical fog that the German navy used to hide its ships in Norwegian fjords during World War II (Amos 2018). Like Gieryn, Jones and Cloke (2002:3) strongly affirm the continued significance of place, critiquing a theoretical trend towards what they call "dematerialized nature"-for example ANT's overemphasis on "topographically fluid networks" that gloss over the distinctiveness of actual places (not to mention the rooted nature of trees). In arbori-culture, materiality and culture are intertwined in ways that are partially unique to each situation, but also expressed through broader social and ecological patterns that shape what human beings and tree beings do in each other's presence. Additionally, Gary Alan Fine's (2003) concept of "naturework" captures the ongoing interpretive process that unfolds as human beings try to make cultural sense out of non-human nature. One form of naturework gives culturally significant trees a post-life, a chance to "live on" and connect with future generations. In this socio-ecological space, we can locate the Anne Frank Sapling Project.

\section{Trees in Motion. Origins of the Anne Frank Sapling Project}

To locate an account is to return it to a place where it was discovered or manufactured, where it is displayed and celebrated, where it gets enacted and reproduced, where it is contested or obscured. Such places may become truth-spots. [Gieryn 2018:3]

In her diaries, Anne Frank wrote about how the beauty and the presence of the chestnut tree growing outside her window inspired her with hope. After her death, the tree became significant to others who read her published diary. They wanted the tree to be cared for as a valued living being, and as a testament to the ongoing impact of Anne Frank's life. 
Since the tree was on private property, various constituencies interacted around the question of how to care for the tree-the city of Amsterdam, local residents, the Support Anne Frank Tree Foundation, the Anne Frank House, and the owner of the garden where the tree stood. By 2005, the tree was found to be seriously diseased. The Anne Frank House asked permission to collect its chestnuts to germinate saplings from the tree. Saplings were provided to a park in Amsterdam and also donated to schools and organizations around the world that had a connection with Anne Frank. ${ }^{4}$ Despite various efforts to save it, in 2010 the approximately 170-year-old tree collapsed after a severe storm. The Anne Frank Center USA (now the AFCMR) took on the project of distributing the remaining eleven saplings to places in the U.S. As AFCMR Director of Education, Beth Slepian (2016), put it, the history of the sapling project "literally grew out of a chestnut tree."

Thomas Gieryn (2018:172) defines "truth-spots" as places where some special geographic feature and a combination of materiality and narration come together to "lend believability and authority to claims or assertions associated with that spot." One could argue that the Anne Frank House and the Sapling Project are part of a larger constellation of "truthspots" that build a narrative of hope based on confronting some of the grimmest realities of human experience in the place where they were enacted, and coming away motivated to prevent such atrocities in the future. Concentration camps and genocide sites are often objects of "dark tourism" (Urry and Larsen 2011), functioning as memorial spaces and places of witness that support a "never again" narrative-the idea that witnessing past horrors of human making

\footnotetext{
4 This website http://www.annefrank.org/en/News/AnneFrank-Tree/ is linked to the Anne Frank House organization, and is undergoing changes.
}

will teach us how to prevent them in the future. Although tree saplings have a gentler presence, they are potentially no less powerful. When a sapling is relocated, it generates another "truth-spot," based on a genetic linkage with the Amsterdam tree and a narrative link between Anne Frank's story and injustices specific to the new place. ${ }^{5}$ This material and symbolic kinship allows the truth-spot narrative and experience to move to other parts of the globe, there to be "displayed and celebrated," and "enacted and reproduced" (Gieryn 2018:3). If successful, it takes root along with the sapling (since both will only flourish in a suitable place), growing local "roots and branches." Like the small saplings themselves, the "never again" narrative is both powerful and fragile, as I will discuss later.

\section{The Clinton Center Site}

From my favorite spot on the floor, I look up at the blue sky and the bare chestnut tree, on whose branches little raindrops shine, appearing like silver, and at the seagulls and other birds as they glide on the wind...As long as this exists, I thought, and I may live to see it, this sunshine, the cloudless skies, while this lasts, I cannot be unhappy. [Anne Frank, The Diary of a Young Girl, February 23, 1944]

This quote is displayed at the Clinton Center's Anne Frank sapling installation. This project originated when Muriel Lederman, then president of the Sisterhood of Congregation B'nai Israel in Little Rock, ${ }^{6}$

\footnotetext{
${ }^{5}$ Thomas Gieryn called my attention to the genetic link in a personal communication.

6 Sisterhood of B'nai Israel "is affiliated with the Reform movement and has as its guiding principle tikkun olam, repair of the world. Members of sisterhood were over-represented in the Women's Emergency Committee to Save our Schools [WEC], the group whose political activity was instrumental in the integration of Little Rock's schools." (Lederman 2009).
} 
heard on National Public Radio about a competition for the saplings, and the requirement that the "installation address not only Anne Frank's legacy and the Holocaust, but also instances of discrimination in the area where the tree would be planted." She thought, "What better place than Arkansas, with the Central High Crisis, the Japanese internment and the Trail of Tears?" (Muriel Lederman, personal communication, July 26, 2016). She envisioned the Clinton Center, with its many visitors, as an excellent prospective location. Eventually she partnered with the Clinton Center to submit a successful proposal in 2009. She made the case that these three episodes of social injustice "were grounded in the same mind-set as the Holocaust-the fear and exploitation of the 'other'"' (Lederman 2009). The proposed logo for the sapling installation was a window frame showing a tree with one green leaf, and the motto "Hope Endurance Justice." Fundraising and other practicalities, including a three-year quarantine imposed on the imported saplings by the U.S. Department of Agriculture, led to a delay of about six years. The sapling was finally installed in October 2015. Even so, it was a surrogate, since the actual sapling was making efforts to adjust to Arkansas' climate at a local greenhouse.

The installation design references Anne Frank's experience of looking out of a window to see the chestnut tree. It mimics a small room with transparent "windows," made up of five etched glass panels-two in front, and three behind the sapling (see: Figure 1). It is prominently located in front of the Clinton Center, and was designed by Ralph Appelbaum Associates, exhibit designers for the Clinton Center and the United States Holocaust Memorial Museum in Washington, D.C. Its transparent modernistic design frames the Clinton Museum and Library just behind it, and as
I will discuss later, its message echoes the Clinton Center's "Bridge to the Future" motif. One front panel focuses on Anne Frank and her connection to the tree, displaying the quote cited earlier. The other panel establishes a connection with the former President Clinton, quoting him: "But let us never forget, the greatest progress we have made, and the greatest progress we have yet to make, is in the human heart. In the end, all of the world's wealth and a thousand armies are no match for the strength of the human spirit." Between the two is a small informational placard with Anne Frank's picture.

\section{Figure 1. Installation design.}

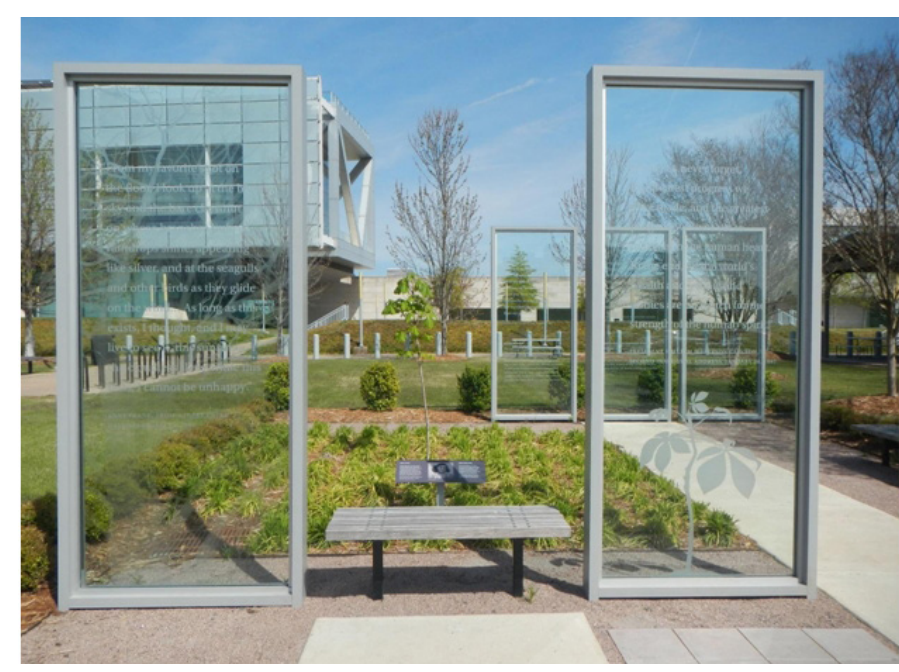

Source: photo Stella Čapek.

The quotations on the three back panels, set behind the sapling and a little bit to the right, recollect injustices in Arkansas, including the displacement of Native Americans through the Indian Removal Act of 1830 (the Trail of Tears passed through Arkansas close to this spot), the internments of Japa- 
nese-Americans at Rohwer and Jerome, Arkansas, during World War II, and the desegregation crisis at Little Rock Central High in 1957, where African-American students ("the Little Rock Nine") faced down jeering crowds and the National Guard to break the segregation barrier. After several iterations during the design process, the following quotes were chosen to invite reflection on the three episodes:

We began every school day with the pledge of allegiance to the flag. I could see the barbed wire fence and the sentry towers right outside my schoolhouse window as I recited the words "with liberty and justice for all," an innocent child unaware of the irony. [George Takei, Rohwer relocation camp resident from 1942-43]

The land we now live on belonged to our forefathers. If we leave it, where shall we go to? All of my nation, friends, relatives are there buried. Since you have expressed a desire for us to be removed, the tears have flowed copiously from my aged eyes. [Chief Heckaton, hereditary chief of the Quapaw during Arkansas's Indian Removal]

The task that remains is to cope with our interdependence-to see ourselves reflected in every human being and to respect and honor our differences. [Melba Patillo Beals, one of the Little Rock Nine]

Each quote arises out of a troubling episode in Arkansas history, affirming the importance of place, whether one is being uprooted from a beloved place, interned in a place against one's will, and/ or seeking inclusion in a place that will nurture one's human rights. The young sapling at the center of the "room" holds these narratives together, and links them to the Anne Frank story. At the same time, it marks a crossroads between different points on a social justice map of Arkansas. Its presence helps reveal a hidden history inscribed in the local landscape, and connects it to a regional and global human rights map. In 2017, the Clinton Center became part of the U.S. Civil Rights Trail, with the sapling installation as "an important part of that designation" (Clinton Presidential Center 2018:3).

The installation's overall message is both somber and inspirational. A Clinton Center brochure states that it "will allow visitors to reflect on the complex history of human rights in Arkansas and throughout the world...These historical episodes serve as poignant and painful reminders of Arkansas's complicated journey toward social justice" (Clinton Presidential Center 2015). A more recent program brochure refers to the installation as "a reminder of the importance of civility and respect for all" (Clinton Presidential Center 2018). Depending on weather and time of day, the sapling installation may be a quiet, empty space or the subject of more human attention. The sapling itself evokes youth and vulnerability, and the bittersweet reality of the tree outliving Anne Frank. It also connects past, present, and future, as the surrounding panels point to social justice work that needs to be done-here and now-on the "complicated journey toward social justice." As a truth-spot, it supports the belief that despite the realities of a brutal past, a more just future is possible.

\section{Framing the Anne Frank Sapling}

This exhibit is a tribute to the resiliency of the human spirit and a poignant reminder that we are all interconnected individuals who share a common humanity. [former President Clinton, 2015] 
The sapling's inauguration on October 02, 2015 was an important framing event, providing legitimating "roots," and setting up an imagined future for the tree. In addition to former President Clinton, "nearly 1,000 guests-including 700 school children, family members of Holocaust survivors, members of the Quapaw Tribe, Japanese-Americans who were interned during World War II, and relatives of the Little Rock Nine" came together to celebrate the installation (Press release 20157). Speeches focused on the tree as a link across time and space. Ronald Leopold (2015), Executive Director of the Anne Frank House in Amsterdam, remarked on the geographical and symbolic connection "from today" between the Clinton Center, the Anne Frank center in New York, and Amsterdam: "We share an important mission. These are places where memories and dreams come together, where the pain of the past and the firm belief in the future go hand in hand."

Thomas Gieryn proposes that places that serve as truth-spots manipulate time, or operate "like time machines," bringing together the past, present, and future. The speeches at the inauguration built a bridge between older and younger generations, and between a troubling past and an imagined hopeful future (although one filled with the hard work of social justice). The sapling was enlisted in this project as speakers described what the fully grown tree might look like and what kind of presence it could have. Leopold (2015) noted that "Young people will come to this beautiful park and will sit in the shadow of Anne's chestnut tree, reflecting on the stories depicted on these panels and on why those stories are still very important to their own lives."

7 See: "President Clinton Dedicates Anne Frank Tree Installation at the Clinton Presidential Center as Part of the Anne Frank Center's Sapling Project." Retrieved June 18, 2020 (http:// www.prweb.com/releases/2015/10/prweb13000057.htm).
Former President Clinton remarked that when the older generation is no longer present, "Young people should be able to go to places like this and see symbols of life, unity, and hope." He added, "And we will remember the wisdom of a 14-year-old girl, whose spirit is depending on us to redeem the years she didn't have."

Interweaving the experience of two 15-year-olds, Anne Frank and Melba Patillo Beals of the Little Rock Nine, Ronald Leopold pointed out that-although worlds apart geographically and historically-both dreamed about a world where "hatred has made way for compassion and the profound awareness that we are all part of one big community, consisting of people with very different backgrounds and beliefs." Juxtaposing two different pasts, he praised the Little Rock Nine, who, "like Anne... did not give in to the hopelessness of the moment," but "opened the doors for millions of others, even though behind those doors there's still much work to be done" (Leopold 2015). The youngest speaker, 17-year-old Lexi Elenzweig (2015), president of Federation of Temple Youth at Congregation B'nai Israel, spoke of the sapling as a "living reminder of Anne Frank's legacy and the tragedy of the Holocaust," but also of hope: "I am just a little older than Anne Frank was when she died. The tree inspired Anne to write about her hopes and dreams for the future. Anne's words, written in her diary, have inspired millions of people around the world, including me. I hope one day our 'little' tree will begin to grow and flourish, and resemble the tree that provided comfort and hope to Anne."

Thus, through the inaugural event, the sapling installation space was simultaneously framed as a place of life and beauty, a symbol of hope, a marker of tragic events, and a workspace, where a trou- 
bling past could be processed and learned from. As Bill Clinton and others emphasized, social justice and human rights in the future need to be based on a "common humanity." Leopold reminded the audience that all of the sad histories commemorated there "were the work of human beings," and that human agency could also create social justice.

\section{Tree Interactions}

April is glorious, not too hot and not too cold, with occasional light showers. Our chestnut tree is in leaf, and here and there you can already see a few small blossoms. [Anne Frank, April 1944]

Our chestnut tree is in full bloom. It's covered with leaves and is even more beautiful than last year-May 1944. [The Anne Frank House n.d. ${ }^{8}$ ]

A children's story written about the Anne Frank Tree in Amsterdam (Gottesfeld 2016) teaches children about Anne Frank, and about a special tree that watched her and "loved the sight of her." Can a tree become an interactive "significant other," extending symbolic interactionist George Herbert Mead's term to non-humans (that is, entities with which/ with whom we value interacting and have a mutual dialogical relationship)? In an earlier paper, drawing on Andrew Weigert's (1997) interpretation of Mead, I argued for such possibilities (Čapek 2006). While that is not my main focus here, I note that, perhaps paradoxically, Anne Frank seems most likely to have had such a relationship with the original tree, even though she could not go outside to touch it or experience it directly. She observed it through the windowpane, where it framed the sky, passing birds, clouds, and changing seasons. She took care-

\footnotetext{
${ }^{8}$ See: http://web.annefrank.org/en/News/Anne-Frank-Tree/.
}

ful note of its small changes, and was attracted to its beauty. Its material presence and aliveness spoke to her, giving her a partial avenue to transcend a keenly felt physical confinement:

Whenever someone comes in from outside, with the wind in their clothes and the cold on their cheeks, I feel like burying my head under the blankets to keep from thinking, "When will we be allowed to breathe fresh air again?"...I long to ride a bike, dance, whistle, look at the world, feel young and know that I'm free, and yet I can't let it show. [Readers' Companion to the Diary of Anne Frank n.d.: $\left.4^{9}\right]$

The living tree and its integration into the ecosystem extended her gaze, gave her solace, and helped her imagine the possibility of a broader universe and a different future. She wrote, "I feel the suffering of millions. And yet, when I look up at the sky, I somehow feel that everything will change for the better, that this cruelty too shall end" (Readers' Companion to the Diary of Anne Frank n.d.:7). In his speech, Ronald Leopold reflected that, for Anne, the tree "represented life in the face of death, the freedom to blossom and prosper."

How can a tree be so powerful? Iris Murdoch's (2014) concept of "unselfing" captures the expansive potential of a human response to beauty, such as the sight of a bird flying. According to David Haskell's reading of Murdoch (as cited in Mowe 2017:59), at such times "we're drawn out of the limitations of our mind, senses and imagination, and drawn into another place," including, possibly, the "lived reality of a completely different species." This allows us to "experience other parts of

\footnotetext{
${ }^{9}$ See: https://bhecinfo.org/wp-content/uploads/AFC-Readers-Companion-Diary-of-AnneFrank.pdf.
} 
our network," including what is non-human and beyond our immediate reach. Such ideas seem to have at least some kinship with Anne Frank's experience of the tree as a boundary-crossing and horizon-expanding entity.

In contrast to this ongoing relationship with the original tree, most visitors to the Clinton Center have a one-time connection with it through the sapling. They look at it and read the surrounding glass panels, and perhaps sit down in the small garden area. Visiting students and teachers sometimes spend more time in this space (see below), interacting with the installation as a whole. Gardeners and caretakers of the landscape have the most direct relationship with the tree (both the actual sapling and the surrogate). Debbie Shock (interview, July 25, 2016, Little Rock), Facilities Manager at the Clinton Center, spends much of her day outside, and has a chance to observe interactions around it. In 2016, she commented:

...every day there's visitors out there reading the panels, looking at the tree-young, old, from every state...it just amazes me. People will just sit on the bench, and you can hear them talk about it. And it brings a lot of conversation out...Lots of families, I've even heard moms and dads talk to younger children about what it is, and I've heard them say, "You'll read the diary of Anne Frank, and when you read it, you'll know this had something to do with it." It just gives you goosebumps when you stand there hearing that.

Shock, a former teacher, observed that "to read it [the diary] is one thing...[but] I think now with these trees growing...students realize there's a lot of history we don't know about, but yet there's hope for the future, and that we need to change things from our past" (Shock, interview, July 25, 2016, Little Rock).

Besides direct tree interactions, the sapling brings with it a variety of educational programs specifically aimed at building dialogue, social interaction, self-awareness, and common ground. As I will discuss below, this bolsters the power of the tree installation as a truth-spot.

\section{Extending the Performativity of the Sapling Installation}

sad barbed justice oppressive innocent irony a nation ashamed

These lines are from a spoken word poem created by students responding to George Takei's quote about Japanese-American internment. As museums and installation spaces have evolved in the later $20^{\text {th }}$ and early $21^{\text {st }}$ century, performative and experiential elements have come to be more expected. The sapling itself is small and grows slowly, and interaction is restricted to looking. The installation design amplifies its physically small presence, and encourages conversation and reflection. The Clinton Center has invested in headphones for visiting schoolchildren, with a narrative that lets them see the tree through Anne Frank's eyes. The sapling is incorporated into programs for different age groups offered by the Clinton Center and-in partnership with the AFCMR-workshops, dramatic performances, talks, and participatory educational programs. In 2013, the AFCMR launched a Confronting Intolerance Today speaker series in conjunction with The Sapling Project to share innovative approaches to combating intolerance. The sapling attracts such programs and expands the audience for them; the programs, 
in turn, amplify the significance and presence of the little tree. It is "performing" by growing, and it is also performing by creating a link to the AFCMR and to global social change networks.

An important function of the educational programs is to uncover the relevance of past events for the present and future. More challengingly, the programs invite personal reflection on one's own possible inadvertent complicity in current injustices. This is a tricky assignment, since no one wants to see themselves as an oppressor. At an educators' workshop in 2016, presenter Beth Slepian from the AFCMR demonstrated how the visual arts (in this case, historic photographs) could be used to approach teaching about injustice in a participatory way. ${ }^{10}$ For example, students imagine the roles of various people in the photographs, and think "beyond the borders," imagining everyone who watched a particular incident. This leads to a discussion about the different roles of "bystanders, helpers, upstanders, and allies." Students reflect on links to their own experiences-for example, bullying at school-and consider what steps they can take, and why. This raises the question "how do I contribute/not contribute to social injustice?" Or, "what can I do, and what can I make sure that I don't do?" Interactive dialogue around a photo or a piece of art (or the sapling) supports discoveries about one's connection to social justice.

Another sapling-related project in 2018 used an object-based approach to work with teachers and students through the Arkansas Declaration of Learning (ADOL) program-a partnership at that time between the U.S. State Department, the Butler

\footnotetext{
${ }^{10}$ More information about this can be found at: https://www. annefrank.com/what-we-do.
}

Center for Arkansas Studies, the Clinton Library, and the Crystal Bridges museum in Northwest Arkansas. These organizations supplied five objects a year, out of which teachers chose four to use as a basis for lesson plans that promote innovative learning and civic engagement projects. The Anne Frank sapling was one of the "objects." It might be combined with a wire sculpture from the Crystal Bridges museum created by artist Ruth Asawa, who was interned as a child at the "relocation center" in Rohwer, and oral histories from the Butler Center, or other possible objects. A participating teacher remarked that these experiences led students "to think about civic engagement, themselves, and the past in an entirely new way." The spoken word poem quoted at the beginning of this section was created by one of the student groups that worked with the sapling installation. A staff member described the sapling as

...a good jumping off point for conversations, and, you know, I think, the way it's presented, I think it makes it easier to have some of the frank conversations with students, not trying to rationalize actions of others, but explaining why they [Japanese-Americans] were interned, and what happened. We want to talk about Anne Frank all day, but we don't want to talk about the U.S. government turning away Jewish immigrants, which is a very complex discussion.

Thus, using the sapling as a "boundary object" linked to the more familiar Anne Frank story, the Clinton Center and the AFCMR have been able to link it to other narratives that open up social justice questions. Nathan Thomas, Educational Programs Associate at the Clinton Foundation, said that teachers reported that students themselves asked for more processing time to have these kinds of conversations, something that they usually did 
not have time for in the regular school curriculum. These can be personally transformative spaces, and can foster future civic leadership skills (Nathan Thomas, interview, August 16, 2018, Little Rock).

Personalized identity is also an important part of the programs. According to an AFCMR handout, “Anne Frank's own arc of self-discovery in her diary is a model to help students understand the power of being themselves, making sense of the world around them, and setting goals to fulfill their dreams to change the world." This emphasizes crafting one's own unique identity even while being in dialogue with the experience of others. One example of this dialogical approach is the performance "A Conversation with Anne," brought to the Clinton Center by the AFCMR. The one-act solo performance draws directly on excerpts from Anne Frank's diary. After the performance, the actress stays in character to answer questions from the audience. The performance is open to a multi-generational audience, but especially aimed at young people. The "conversation" personalizes and humanizes Anne Frank, including her dream to be a published writer, her sometimes "sassy" comments, and her desire to experience her full self. It also points to her courage, resistance, restlessness, and hope-in other words, it presents a complex human being, not an abstract notion of a "hero." This makes her easier to relate to as a role model, while also teaching about the dangers of intolerance.

Like Leopold's speech, the AFCMR programs noticeably use "frame bridging" (Snow et al. 1986) across time and space to build a connection between different groups' perspectives and experiences. The performance "Letters from Anne and Martin" draws on two famous documents: Anne Frank's diary and Dr. Martin Luther King Jr.'s “Let- ter from Birmingham Jail." Actors use excerpts from these writings to enact an imagined dialogue between the two about "their hopes and plans for a peaceful and unified world." Like "A Conversation with Anne," this performance generates audience discussions. Such programs continue to expand, alongside the sapling that grows and serves as a symbolic gateway to broader conversations. As I will discuss below, the experiential and dialogical learning exemplified by these programs is especially sought after in contemporary museum exhibits.

\section{Museums and Social Justice in a Global Context}

A more globally interconnected world has led to new debates about the role of museums and exhibit spaces, and particularly, their involvement in social justice issues. A growing number of museums visibly support human rights. Of course, this varies depending on economic, political, and other interests that shape museum spaces and "define the boundaries of possible action and the form and tone of particular exhibitions" (Cameron 2006:29). Nevertheless, the visibility of social justice focused museums has increased, and some are part of global social justice networks-for example the Social Justice Alliance of Museums (SJAM) or the Federation of International Human Rights Museums (FIHRM), which "encourages museums which engage with sensitive and controversial human rights themes... to work together and share new thinking and initiatives in a supportive environment" (FIHRM 2018 ${ }^{11}$ ). The SJAM website notes that while the definition of social justice "has different meanings in different

\footnotetext{
${ }^{11}$ See: "About Us." https://www.fihrm.org/home/. Retrieved September 14, 2018.
} 
parts of the world...there is a common denominator to fight injustice and promote equality" (SJAM 2018 ${ }^{12}$ ). Institutions like the U.S. Holocaust Memorial Museum (USHMM) are critical nodes in a global network, offering model programs and engaging in broad outreach. The USHMM relates its slogan "Never Again" not only to the Holocaust, but to other sites of genocide and potential genocide, worldwide. ${ }^{13}$ Such approaches mark a shift from "this shouldn't happen here" to "this shouldn't happen anywhere, to anyone" (Jasper 2015:275). Collectively, this also helps to build a "transnational memory" (Gluck 2007), an essential piece of social justice work across international borders. The Little Rock sapling site is part of this constellation of social justice spaces and places.

Research literature on museums documents the increasing importance of participatory learning and dialogical approaches like the ones I described in the previous section. Liz Ševčenko (2010:25) argues for "developing interpretation not around a linear narrative, but around open-ended questions on current issues, and giving people the time and space to engage in exchanges with each other about them." Fiona Cameron (2006:23), in a discussion of "edgy" and controversial exhibits, references sociologist Zygmunt Bauman's ideas about postmodernity (2002:138) to claim that since "morality in a postmodern world...is re-personalized and individual, institutions need to decisively move away from

\footnotetext{
12 See: https://incluseum.com/2014/11/17/social-justice-alliance-of-museums-sjam. Retrieved September 13, 2018.

13 The USHMM states that its Center for the Prevention of Genocide "works to educate, engage, and inspire the public to learn more about past genocides-such as those in Rwanda, Bosnia, and Darfur-and to consider what they can do to prevent these atrocities in the future. [It] also works to galvanize policy makers both in the US and around the world to create the tools and structures needed to avert the next crisis" (see: https://www.ushmm.org/information/about-the-museum).
}

framing exhibition content according to a consensual, collective morality to one that also encourages self expression." She also draws on Chakrabarty's (2002) contrast between "pedagogic" and "performative" forms of democracy, the latter relying on a more interactive and dialogic experience. She concludes that a "performative genre" is especially appropriate for controversial topics, and that museum staff can function as "expert mediator, informant, and facilitator" (Cameron 2006:23). This leaves room for audiences to do interpretative work. Furthermore, Gayle McPherson (2006) points out that museums are increasingly under pressure to generate revenue through market-based fundraising. She concludes that, when combined with new technologies and a shift in leisure behavior patterns that seek out museums as places of recreation, museums will become "hybrid places" (Kotler 2001). This, too, supports a performative genre.

Critiques of social justice or "conflict" museums have focused on several key themes. One is an overreliance on emotion-based approaches. Lisus and Ericson (1995) refer to some conflict museums as "emotions factories," noting that emotional experiences often have no lasting impact. Hamber (2012:272-273) points to a more subtle challenge: that "conflict museums can create an overidentification with the victim, precluding people from thinking of themselves as potential victimizers" or understanding power relations. A danger of the Never Again discourse, he claims, is that "it can create an idealized and imagined concept of the future that is devoid of context and political reality," or overemphasizes individual agency rather than social structure. Critics also point to forms of nostalgia that produce uncritical "hagiographies" of key personages (Pickering and Keightley 2006). By contrast, Svetlana Boym (2007:13) argues that "re- 
flective nostalgia" can be mobilized for positive social change, allowing reflection on the complexities of past and present to inspire a positive, realistic basis for the future-one that "does not shy away from the contradictions of modernity."

Considering the "performative genre" programs linked to the Clinton Center sapling installation in light of these critiques, it is clear that many of these pitfalls have been avoided. The Clinton Library and Museum is not a "conflict museum," but the sapling site is both gentle and "edgy." It brings together the "feel-good" appreciation of the ongoing life of the Anne Frank tree (sapling) and the complexity and difficult histories of erasure and exclusion. As discussed earlier, interactive performances like "A Conversation with Anne" are far from hagiographies. Contrary to Hamber's critique, the AFCMR sponsors a range of educational activities that help individuals "connect the dots" between social actions that made the Holocaust possible and current injustices that they can recognize (e.g., bullying in the schools, or the treatment of immigrants, or discrimination against LGBTQ persons). These programs also ask participants to connect the dots on the inside, reflecting on how they might become a "potential victimizer"-even if only through a complicit silence or previously unrealized privilege. Uncovering this is not easy work. Perhaps the presence of the growing sapling and its message of hope softens these encounters without trivializing them. Nathan Thomas (interview, June 01, 2016, Little Rock) pointed out that "Desegregation is really heavy, Japanese-American internment is really heavy, everything in the exhibit is heavy, but the tree lightens it." Likewise, to counteract this "heaviness," the programs build up a collective identity of shared humanity; instead of "othering," they focus on how all human beings are connected (as reflected in Melba Patillo Beals' quote on the installation panel). Thus, as a "truth-spot," the sapling installation energizes both personal and collective insights into social justice, without falling into unreflective nostalgia or avoiding challenging personal questions. However, because of the challenging task of confronting difficult subjects, as well as changing expectations about museum installation spaces, constant innovation is required, and the best practice models are shared through a global network.

In George Herbert Mead's terms (2015), the self is a process that continually evolves through social interaction, which also shapes our understanding of the past, present, and possible futures. This implies that the future is subject to intervention and reinvention, especially if based in a pragmatic understanding of the past and present. Museum installations that encourage critical thinking about one's own identity and engage in bridge-building between diverse groups in the interests of future social justice are premised on this transformative possibility. Performative and dialogical approaches facilitate an imaginative rehearsal of a possible future. They also engage with the past, doing what Hamber (2012:269) calls "memory work." Associated with "memory sites" (Young 1993), this typically includes "outreach youth education programs, traveling exhibits, tours, lecture series, and storytelling sessions," whose goal is "revealing the past...to prevent future forms of atrocity" (Hamber 2012:269). Eviatar Zerubavel (2003:4) has explored how different groups are socialized into "mnemonic traditions" that include "social norms of remembrance that tell us what we should remember and what we should essentially forget." Museums that focus on embodied, interactive, and dialogical social justice exhibits invest in the idea of mnemon- 
ic resocialization, a process through which we can learn new things that affect what we remember and forget, and that bring us into a more inclusive relationship with others. The Clinton Center and AFCMR programs provided many illustrations of this approach to the past, present, and future.

Returning to the truth-spot concept, what kind of truth do such practices generate? Although expertise has a place, truth is seen as a process of discovery and co-creation based on interactive, dialogical experiences between different groups. In Ševčenko's terms, this yields a non-linear, more open-ended narrative. Facts are not abandoned, but truth is intersectional, drawing on a variety of perspectives. This understanding of truth is postmodern in the sense that the kaleidoscope shifts slightly to accommodate unique personal identity construction. However, it still focuses on common ground. As Lexi Elenzweig said in her speech at the sapling inauguration: "My hope is that the Anne Frank tree will come to represent something different for each observer as we look through these windows, allowing each of us to see through the eyes of others and to understand that we are all rooted in the same ground."

\section{The Tree as Immigrant}

Trees do bring a creative agency into all manner of relational achievements which humans enroll, such as fruit production, timber production, and landscape production. But, they appear to work to other agendas and operate in other networks outside of or in conflict with human enrolled networks. [Jones and Cloke 2002:215]

Trees are "palpable living individuals" (Jones and Cloke 2002:3). And, as Nathan Thomas points out, the sapling itself is an immigrant. Like many other migrants, including the Frank family, and the groups portrayed on the glass panels, it has struggled to survive despite being "out of place." He commented, "Just the idea of trees having to deal with, especially in Little Rock, the cultures we have in the soil and the bugs and the seasons we have-it's just not suited for it. But, if you slowly bring the tree into the climate, apparently-we'll find out-it can adapt." He saw the adaptation theme as a potential "deeper conversation to have" in the future, another link between Anne Frank and the tree.

The Sapling Project depends on local ecological knowledge and an understanding of the tree's original environment, so that it can be appropriately cared for. After a three-year quarantine to prevent the possible spread of disease, some saplings went to places with a climate more similar to the Netherlands. But, the Clinton Center sapling faces the challenge of higher temperatures in the U.S. South. Although it receives excellent care, the adaptation is not easy. As mentioned earlier, the sapling planted at the installation ceremony was a surrogate for the actual sapling that was being acclimated at a local greenhouse (along with some of its more distant relatives as backups). When I visited the sapling at the greenhouse on a very hot and humid summer day, the caretaker expressed the opinion that maybe "It will never get used to being here." He expressed misgivings about the relocation process of the saplings and concern about their future wellbeing. I learned during my project that Central High had applied earlier for its own sapling, but it did not survive. When Steven Goldstein from the AFCMR visited the Clinton center in 2017, he mentioned that a second sapling would be coming to Central High, giving Arkansas some "brag- 
ging rights" as the only state with two saplings. But, someone from Central High, sitting in the row in front of me, loudly whispered to a neighbor, "I don't even want it. There's no information, and the kids don't know how to take care of it." While this problem could be solved, an ecological perspective on the saplings yields a cautionary tale about the dangers of taking an instrumental view of trees (or other non-human beings). They have their own "agendas" for survival and may not serve human desires. Olivia Judson (2009:2) points out that, like human beings, plants "are shaped by what happens to them, and alter their responses to future events based on their experiences in the past." Perhaps we should be doing "memory work" not only with human beings in mind.

Climate change brings additional challenges and complexities. Trees all over the globe are increasingly vulnerable to damage through increasingly extreme weather events. For example, there is good reason to believe that the destruction of the original Anne Frank tree and the tree in Grand-Pré, Nova Scotia was accelerated by climatic events that weakened them even before intense storms killed both in 2010. The problem of ecological survival raises an interesting question about authenticity. The Anne Frank saplings derive their power to inspire from being direct descendants of the original Amsterdam tree. But, this authenticity cannot be recreated just anywhere. What if the original sapling, symbol of "Hope Justice Endurance," cannot survive? Would a quick substitution suffice? Would a permanent surrogate sapling provide the same kind of authenticity, over time? Could having a permanent surrogate sapling be interpreted positively, as a lesson in limits, resilience, and flexibility in a globally and climatically changing world, and embraced as a new kind of truth?

\section{Conclusions}

All beginnings contain an element of recollection. [Connerton 1989:6]

My paper has been about memory work that touches on the future as well as the past, using the Anne Frank sapling installation as a focus. I have looked into the somewhat mysterious role that trees play in human experience, using the lens of arbori-culture, which sees trees as both socially constructed and materially agentic entities. I have also proposed that the sapling installation can be seen as part of an interrelated global network of truth-spots. Thomas Gieryn (2018:3) has asserted that no two truthspots follow "the exact same recipe," but in each case "place itself is not merely an incidental setting where some idea or assertion just happens to gain credibility, but a vital cause of that enhanced believability." The motto of the Clinton Museum and Library is "a Bridge to the Future," playing on the architectural design that makes it appear to hang partly in the air by the Arkansas River, near where the Trail of Tears once passed. This particular place is important, with its constellation of past events, present significance, and the imported tree sapling that connects it to yet other places and histories. The sapling stands at the center of many interlaced immigration stories and a geography of previous suffering. The location has the double advantage of a standard attraction-a national presidential library-and a unique combination of elements in the sapling installation. If the sapling were moved to a different place, the entire configuration (and the message of the truth-spot) would change. Yet, as a symbolic and material offshoot of other truthspots like the Anne Frank House, it also shows that belief can be portable, even though inflected differently in each local place. 
Different layers of truth (and meta-truth) adhere to this place. The installation and its accompanying programs support the compelling belief that doing the necessary hard work to understand past and present injustices can lead to a more just future. This belief allows hope to live on, as the sapling (or perhaps a surrogate) grows in place. The installation stands out as a place where "nature" (in the form of a tree) is presented as a healing force, grounded in its ability to regenerate. The tree enhances the place because it is physically part of the original Anne Frank tree, but also because of what a tree is and does. As Rabbi Barry Block of Little Rock (interview, July 20, 2017) commented, “I don't think it was random that she [Anne] was drawn to a tree." But, the installation also draws the gaze beyond the sapling, to what is more challenging. It supports the "never again" narrative, but always with the important caveat that the future depends on taking action for social justice, after being honest about the past. Other truths may open up here, too, as participants not only ask "what happened here?" but also, "who am I in this place?" The setup invites each individual to find answers in terms most relevant to their own experience, leaving room for individual interpretation. This seems to be the hallmark of a more modern approach to truth, one that also fits with museums' changing missions. From a meta-truth perspective, then, the truth supported here is a process of ongoing, intersectional discovery. Judging by the virulent response from those who believe that truth is

\section{References}

Amos, Jonathan. 2018. "Nazi Legacy Found in Norwegian Trees." British Broadcasting Company (BBC). Science E Environment April 11, 2018.

Blumer, Herbert. 1969. Symbolic Interactionism: Perspective and Method. Englewood Cliffs, NJ: Prentice Hall. fixed, and who label anything that challenges their views as "fake news," the "never again" narrative is fragile and always challenged. The same "othering" that produced the Holocaust is alive and well in contemporary inequalities and genocides.

Truth-spots are necessarily selective creations. We also live among shifting "truth" landscapes in the world. Eva Schloss, who became Anne Frank's step-sister after her mother married Anne's father after the war, commented on a disturbing parallel between the U.S. refusal to take in more Jewish refugees in the 1940s and President Donald Trump's proposal for a wall, and a ban on Muslim and Syrian refugees (Salzillo 2016). The stirring up of hatred and refusal to condemn racism, white nationalism, conspiracy theories, and hate crimes caused her to question what we have learned from history. This hatred has not left the tree saplings unscathed. In May 2018, one of the saplings in the town of Waalwijk in the Netherlands was attacked, and the commemorative plaque stolen. Park rangers bandaged it after its first injury, but it was deliberately broken a second time (Jerusalem Post 2018). As Ronald Leopold stated so clearly in his speech in Little Rock, the doors of social justice open, but there is much hard work to be done. That message is already embodied in the Clinton Center installation, but underlined and amplified by current global events. The tree sapling is a small presence, but what "swirls around it" (Jones and Cloke 2002) is powerful.

Bowker, Geoffrey C. et al. 2016. Boundary Objects and Beyond: Working with Leigh Star. Cambridge, MA, London: MIT Press.

Boym, Svetlana. 2007. "Nostalgia and its Discontents." The Hedgehog Review 9(2):7-18. 
Brosse, Jacques. 1998. "Postface: The Life of Trees." Pp. 299303 in The Social Life of Trees: Anthropological Perspectives on Tree Symbolism, edited by L. Rival. Oxford, New York: Berg.

Cameron, Fiona. 2006. "Beyond Surface Representations: Museums, 'Edgy' Topics, Civic Responsibilities and Modes of Engagement." Open Museum Journal: Contest and Contemporary Society 8.

Čapek, Stella M. 2006. "Surface Tension: Boundary Negotiations around Self, Society, and Nature in a Community Debate over Wildlife. Symbolic Interaction 29(2):157-181.

Čapek, Stella M. 2012. "Encountering Nova Scotia: Doorways into Silence and Voice." Creative nonfiction essay read at the Association for Study of Literature and Environment Off-Year Symposium, June 15, 2012, Juneau, Alaska.

Chakrabarty, Dipesh. 2002. "Museums in Late Democracies." Humanities Research IX(1):5- 12.

Clinton Presidential Center. 2015. "Educational Programs 2015-2016." Clinton Presidential Center, Little Rock, Arkansas.

Clinton Presidential Center. 2018. “Educational Programs 2018-10." Clinton Presidential Center, Little Rock, Arkansas.

Connerton, Paul. 1989. How Societies Remember. New York: Cambridge University Press.

Elenzweig, Lexi. 2015. "Remarks at Dedication of Anne Frank Tree," October 02, 2015. From Muriel.

Fine, Gary Alan. 2003. Morel Tales: The Culture of Mushrooming. Urbana: University of Illinois Press.

Fox, Nick. 2011. "Boundary Objects, Social Meanings and the Success of New Technologies." Sociology 45(1):70-85.

Gieryn, Thomas F. 2018. Truth-Spots: How Places Make People Believe. Chicago: University of Chicago Press.

Gluck, Carol. 2007. "Operations of Memory: Comfort Women and the World." Pp. 47-77 in Ruptured Histories: War, Memory, and the Post-Cold War in Asia, edited by S. M. Jager and R. Mitter. Cambridge, MA: Harvard University Press.

Gottesfeld, Jeff. 2016. The Tree in the Courtyard: Looking Through Anne Frank's Window. New York: Knopf Books for Young Readers.
Hamber, Brandon. 2012. "Conflict Museums, Nostalgia, and Dreaming of Never Again." Peace and Conflict: Journal of Peace Psychology 18(3):268-281.

Ingold, Tim. 2011. Being Alive. London: Routledge.

Jasper, James M. 2015. The Art of Moral Protest : Culture, Biography, and Creativity in Social Movements. Chicago: University of Chicago Press.

Jerusalem Post. 2018. "Sapling from Anne Frank's Tree Twice Cut Down in Holland Park." Retrieved May 22, 2018 (https:// www.jpost.com/Diaspora/Sapling-from-Anne-Franks-treetwice-cut-down-in-Holland-park-558063).

Jones, Owain and Paul J. Cloke. 2002. Tree Cultures: The Place of Trees and Trees in Their Place. Oxford, New York: Berg.

Judson, Olivia. 2009. "Memories in Nature." New York Times, Opinion Pages, 1-4. December 29.

Kotler, Neil. 2001. “New Ways of Experiencing Culture: The Role of Museums and Marketing Implications." Museum Management and Curatorship 19(4):417-425.

Latour, Bruno. 1993. We Have Never Been Modern. New York: Harvester Wheatsheaf.

Latour, Bruno. 2004. “Non-Humans." Pp. 224-227 in Patterned Ground: Entanglements of Nature and Culture, edited by S. Harrison, S. Pile, and N. J. Thrift. London: Reaktion Books.

Lederman, Muriel. 2009. Application for an Anne Frank Sapling at the Clinton Center. May 2009.

Leopold, Ronald. 2015. Speech by Ronald Leopold, Executive Director. The Anne Frank House October 02, 2015. AFCMR.

Lisus, Nicola and Richard Ericson. 1995. "Misplacing Memory: The Effect of Television Format on Holocaust Remembrance." British Journal of Sociology 46(1):1-19.

MacNaghten, Phil and John Urry. 2000. "Bodies in the Woods." Body \& Society 6(3-4):166-182.

McPherson, Gayle. 2006. "Public Memories and Private Tastes: The Shifting Definitions of Museums and Their Visitors in The UK." Museum Management and Curatorship 21(1):44-57.

Mead, George Herbert. 2015. Mind, Self, and Society. Chicago: University of Chicago Press. 
Mowe, David. 2017. "Listening to Trees: An Interview with David Haskell." Spirituality \& Health November/December: 54-59.

Murdoch, Iris. 2014. The Sovereignty of Good. New York: Routledge

Pickering, Michael and Emily Keightley. 2006. “The Modalities of Nostalgia." Current Sociology 54:919.

Rival, Laura M. 2001. The Social Life of Trees: Anthropological Perspectives on Tree Symbolism. Oxford, New York: Berg.

Salzillo, Leslie. 2016. “Anne Frank's Stepsister Who Survived Auschwitz Has Strong Words for Donald Trump." Daily KOS, Friday January 29, 2016.

Schama, Simon. 2004. Landscape and Memory. London: Harper Perennial.

Ševčenko, Liz. 2010. "Sites of Conscience: New Approaches to Conflicted Memory.” Museum International 62:20-25.
Slepian, Beth. 2016. Educators' Workshop. Clinton Center. June 24, 2016.

Smith, Genaro Kỳ Lý. 2014. The Land Baron's Sun: The Story of Lý Loc and His Seven Wives. Lafayette: University of Louisiana at Lafayette Press.

Snow, David A. et al. 1986. "Frame Alignment Processes, Micromobilization, and Movement Participation." American Sociological Review 51(4):464-481.

Urry, John and Jonas Larsen. 2011. The Tourist Gaze 3.0. Los Angeles, London: SAGE.

Weigert, Andrew J. 1997. Self, Interaction, and Natural Environment: Refocusing our Eyesight. New York: SUNY Press.

Young, James E. 1993. The Texture of Memory: Holocaust Memorials and Meaning. New Haven, London: Yale University Press.

Zerubavel, Eviatar. 2003. Time Maps: Collective Memory and the Social Shape of the Past. Chicago: University of Chicago.

\section{Citation}

Čapek, Stella M. 2020. “Trees as Dialogue: Negotiating Boundaries with the Anne Frank Sapling Project.” Qualitative Sociology Review 16(3):28-47. Retrieved Month, Year (http://www.qualitativesociologyreview.org/ENG/archive_eng.php). DOI: http:// dx.doi.org/10.18778/1733-8077.16.3.03 